\title{
Characterisation of ocular melanoma with cutaneous melanoma antibodies
}

\author{
J BOMANJI,' A GARNER, ${ }^{3} \mathrm{~J}$ PRASAD,${ }^{3}$ D M ALBERT, ${ }^{+} \mathrm{J}$ L HUNGERFORD,${ }^{2}$ \\ M GRANOWSKA,' AND K E BRITTON'
}

From the Departments of 'Nuclear Medicine and 'Ophthalmology, St Bartholomew's Hospital, London, the ${ }^{3}$ Department of Pathology, Institute of Ophthalmology, Moorfields Eye Hospital, London, and the ${ }^{4}$ Department of Ophthalmology, Harvard University, Boston, USA

SUMmARY It can be difficult to distinguish between various forms of pale intraocular tumour, and in particular between an amelanotic malignant melanoma, a choroidal haemangioma, and a solitary metastasis. If a monoclonal antibody specific for melanoma could be identified, it might be radiolabelled to provide a scanning technique which could distinguish between an ocular melanoma and a similar lesion. This pilot, in vitro study was undertaken to determine if monoclonal antibody against cutaneous melanoma recognises any antigenic similarity in ocular melanomas. Three cutaneous melanoma MoAbs $225 \cdot 28 \mathrm{~S}, 376 \cdot 96 \mathrm{~S}$, and $763 \cdot 24 \mathrm{~T}$ and a non-specific MoAb HMFG2 were studied. Cell impressions were obtained from fresh ocular malignant melanomas. Standard staining techniques with immunofluorescence were used. MoAb 225.28S, 376.96S, and 763.24T were positive in melanomas with a dominant epithelioid cell type and in those with a dominant spindle cell type. It is concluded that MoAb 225.28S, 376.96S, and 763.24T may be suitable for imaging ocular melanomas after labelling with ${ }^{123} \mathrm{I},{ }^{111} \mathrm{In}$, or ${ }^{49 \mathrm{~m}} \mathrm{Tc}$.

Melanoma is the commonest primary malignancy of the eye. There are two areas of difficulty in the clinical diagnosis of the tumour in the uvea. On the one hand a small pigmented malignant melanoma may be difficult to distinguish from a benign naevus, a melanocytoma, or a carcinoma of the retinal pigment epithelium. Qn the other, it may not be easy to decide whether a non-pigmented mass lesion is an amelanotic melanoma, a choroidal haemangioma, or a metastasis.

Choroidal biopsy is technically possible but many small melanomas are too posterior for the procedure to be contemplated without undue risk of complications. Fluorescein angiography and ultrasound may help to strengthen the clinical diagnosis, and in centres specialising in ocular tumours some $98 \%$ of these lesions are diagnosed correctly by non-invasive investigations. ${ }^{12}$ Nevertheless it remains difficult to assess the malignant potential of some of the smaller lesions. Small melanomas can be destroyed in situ by photocoagulation or radiation with good visual results. The success of these techniques might be

Correspondence to Dr J Bomanji, Department of Nuclear Medicine, St Bartholomew's Hospital, West Smithfield, London EC1A 7BE. more credible if confirmation of the nature of the tumour could be obtained by using a more specific imaging technique.

Recently, monoclonal antibodies (MoAb) have been used extensively in vitro and in vivo as tumour markers for diagnostic purposes. Radiolabelled MoAb have been used for diagnostic imaging of ovarian carcinomas, ${ }^{3}$ colonic carcinomas, ${ }^{4}$ and cutaneous melanomas. ${ }^{5}$ The possibility of using radiolabelled $\mathrm{MoAb}$ for imaging ocular melanomas remains to be explored.

This pilot, in vitro study was undertaken to determine if monoclonal antibodies against cutaneous melanoma recognise any antigenic similarity in ocular melanomas. If so they can be labelled with gamma-emitting radioisotopes like iodine-123, technetium-99m, and indium-111 and used for diagnostic imaging of ocular melanomas with an external gamma camera.

\section{Materials and methods}

Three MoAb, 225.28S, 376.96S, and 763.24T, against cutaneous melanoma were used (provided by 
Sorin Biomedica). These are $\operatorname{IgG}_{2}$. MoAb 225.28S and $763 \cdot 24 \mathrm{~T}$ recognise high molecular weight melanoma-associated antigens (HMW-MAA) which are membrane bound and glycoprotein. ${ }^{(.) 1)}$ MoAb 376.96S recognises low molecular weight melanomaassociated antigens. A non-specific MoAb against human milk fat globulin (HMFG2)" was used as a control.

The first screening method was immunofluorescein staining on: $(a)$ cultured ocular melanoma cell lines established from choroidal melanoma OM431 (epithelioid cell);" (b) cell impressions made from fresh ocular melanoma tumour cells obtained from six patients. Standard staining techniques were used. The MoAb were used in a concentration of 1:50 and applied to the cell impressions and frozen tissue sections. These were incubated for one hour at room temperature in a humid environment and washed gently with phosphate buffered saline (PBS) $(\mathrm{pH}$ 7.2). To this, antimouse rabbit antibody with fluorescein (Dako) was applied in a concentration of 1:30 and incubated for a further 30 minutes. The preparations were then washed gently with PBS, and the samples were mounted in buffered glycerol and examined under a fluorescent microscope in $495 \mathrm{~nm}$ excitation light.

The second method used was the avidin-biotin technique. The MoAb were applied in concentration of 1:50 on the preparations incubated for one hour at room temperature in a humid environment, and were washed gently with PBS. To this the antimouse biotinylated whole antibody (sheep) was applied in a concentration of 1:150 and incubated for 30 minutes at room temperature in a humid environment. The preparations were washed and incubated with 1:400 diluted peroxidase labelled streptavidin biotin complex (Amersham International) for 30 minutes. This was followed by a gentle wash with PBS and then incubated for 20 minutes at $37^{\circ} \mathrm{C}$ with $0 .(2 \%$ - 3 amino-9-ethylcarbozol in $50 \mathrm{mM}$ acetate buffer ( $\mathrm{pH} 5$ ), containing $0.3 \%$ hydrogen peroxide. The reaction was stopped by giving a gentle wash to the preparations in distilled water. The preparations were counterstained with freshly prepared Mayer's haematoxylin to achieve light staining of the samples. The preparations were then mounted in Kaiser's glycerol jelly and viewed under the light microscope. This procedure was also repeated after melanin bleaching had been carried out.'

\section{Results}

Cell impressions of patient 1: MoAb 376.96S and 763.24T showed a strong positive fluorescence. MoAb 225.28S showed a positive fluorescence (Fig. 1), and MoAb HMFG2 showed no fluorescence (Table 1). The histology of this specimen showed a heavily pigmented malignant melanoma of the epithelioid cell type.

Staining of cell impressions of patient 2 was negative with all the MoAb except MoAb 763.24T. $\mathrm{MoAb} 763 \cdot 24 \mathrm{~T}$ showed a doubtful positive fluorescence. The histology of this specimen showed a heavily pigmented malignant melanoma consisting of interweaving fasiculae of epithelioid and spindle $B$ cells.

Cell impressions of patients 3 and 4 : the MoAb $225 \cdot 28 \mathrm{~S}$ showed a positive fluorescence. MoAb $376.96 \mathrm{~S}$ showed a doubtful positive fluorescence and MoAb 763.24T a positive fluorescence in patient 3,
Fig. 1 Positive immunofluorescence staining of cell impressions with MoAb 225-28S.

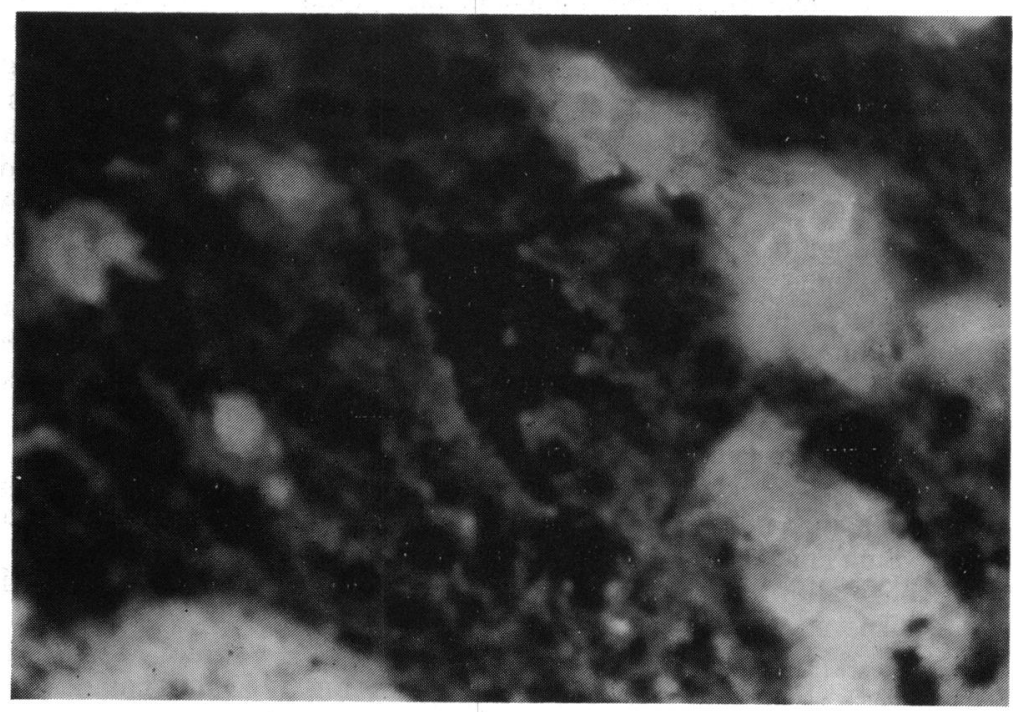


Table 1 Immunostaining responses of uveal melanoma cells

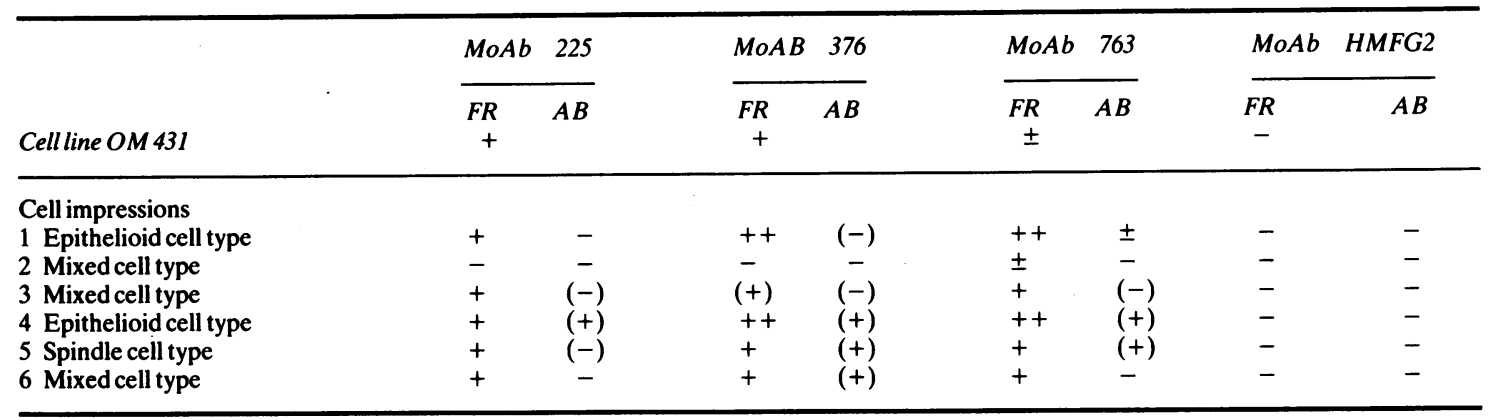

FR $=$ Fluorescence, $\mathrm{AB}=$ Avidin-biotin,$++=$ Strong positive,$+=$ Positive,$\pm=$ Doubtful positive,$-=$ Negative,()$=$ Unreliable

and both showed a strong positive fluorescence in patient 4. There was no fluorescence with MoAb HMFG2. Histological examination of the tumour revealed in both cases variably pigmented malignant melanomas of mixed type but with a predominance of epithelioid cells.

Cell impressions of patients 5 and 6 showed a positive fluorescence with MoAb 225.28S, 376.96S, and 763.24T. The Moab HMFG2 was negative. Histology of both tumours showed pigmented malignant melanoma of mixed type.

The staining carried out on cultured ocular melanoma cell line OM 431 (epithelioid cell) showed a positive fluorescence with MoAb 225.28S and 376.96S a doubtful positive with MoAb 763.24T and no fluorescence with MoAb HMFG2.

The responses to monoclonal antibody with the avidin-biotin method were in several instances almost impossible to evaluate because of the melanin present in three of the tumours. Attempts to circumvent this problem by bleaching the cell impressions were unsatisfactory, since it was difficult to take the process to completion without damaging the tumour cells and causing a diffuse, non-specific peroxidase reaction. Non-specific staining of the background also added to the difficulty of interpretation.

\section{Discussion}

Cutaneous melanocytes located primarily in the epidermis are of neuroectodermal origin, whereas melanocytes of the uveal stroma appear to derive from the neural crest. This suggests that some differences as well as similarity in the antigenicity might be found, and the present limited study was undertaken to determine the extent to which monoclonal antibodies against cutaneous melanoma cells recognise the antigenically similar sites on the surface membrane of uveal malignant melanoma cells.
Testing three such antibodies on cell impressions from six different choroidal melanomas has shown that there is indeed some sharing of antigens. Five of the tumours bound all three MoAbs. A sixth tumour gave a minimal response limited to weak immunofluorescence against just one of the three antibodies, MoAb 763.24T.

These preliminary findings suggest that monoclonal antibodies to malignant melanomas of the skin, which are becoming increasingly available for clinical application, might be used to detect intraocular melanoma. There are several ways in which this potential might be exploited.

One feasible application would be distinguishing uveal melanomas from other intraocular tumours in a non-invasive manner by measuring the uptake of radiolabelled melanoma-specific antibodies. A non infrequent source of diagnostic confusion is presented by choroidal haemangiomas and by bloodborne metastases from a distant site. In this context it is relevant to inquire as to the degree of crossreactivity for the monoclonal antibodies raised against melanoma cells to cells of other histogenesis. Precise information concerning the antibodies used in this study is not available, but others ${ }^{13-15}$ have described cross-reactivity between some monoclonal antibodies raised against human cutaneous melanoma cells and astrocytomas, medulloblastomas, and unspecified epithelial cancers. It is possible that the antibodies are recognising neuroectodermal and to some extent related neural crest differentiation antigens. Nevertheless, the risk of making a false diagnosis of uveal melanoma may be reduced by using not just one but several antibodies, since the degree of antigen sharing is not complete.

Differentiation between malignant and benign pigmented lesions within the eye can be another source of difficulty. The binding of monoclonal antibodies against skin melanomas to uveal naevi has yet to be tested, but a study by Seeger and 
coworkers $^{15}$ suggests that some uptake might be expected. The same study did demonstrate, however, that malignant melanoma cells have a significantly greater avidity for antibody than do normal melanocytes. ${ }^{15}$ It may be necessary, therefore, to distinguish malignant lesions from naevi by quantitative refinement of the scanning techniques.

Use is already made of radiolabelled monoclonal antibodies $^{16}$ to image metastases of skin melanomas at distant sites, and, given the sharing of tumour associated antigens, the same approach can be used to identify metastasis of uveal melanoma. This could be a major clinical application of the monoclonal antibodies.

Monoclonal antibodies of the type described could also be of value in histological diagnosis if combined with an immunofluorescent or immunoperoxidase technique. As such they would be particularly relevent to the differential diagnosis of nonpigmented spindle cell tumours in the eye.

We thank Sorin Biomedica company for providing the antibodies for this project and Professor Scassallati for his help and advice. We acknowledge the support of Imperial Cancer Research Fund (Mr JL Hungerford and DrM Granowska) and the Joint Research Board of St Bartholomew's Hospital (Dr J Bomanji).

\section{References}

1 Robertson DM, Campbell RJ. Errors in the diagnosis of malignant melanoma of the choroid. Am J Ophthalmol 1979; 87: 269-75.

2 Char DH, Stone RD, Irvine AR, et al. Diagnostic modalities in choroidal melanoma. Am J Ophthalmol 1980; 89: 223-30.

3 Granowska M. Britton KE, Shepherd JH, et al. A prospective study of I-123 labeled monoclonal antibody imaging in ovarian cancer. J Clin Oncol 1986; 4: 730-6.

4 Farrands PA, Pimm MV, Embletom MJ. Radioimmunodetection of human colorectal cancer by an anti-tumour monoclonal antibody. Lancet 1982; ii: 397-400.
5 Buraggi GL, Turrin A, Cascinelli N, et al. Radioimmunodetection of melanoma: preliminary results of a prospective study. Int J Biol Markers 1986; 1: 47-54.

6 Wilson BS, Iami K, Natali PG, Ferrone S. Distribution and molecular characterization of cell-surface and cytoplasmic antigen detectable in human melanoma cells with monoclonal antibodies. Int J Cancer 1981; 28: 293-300.

7 Bumol TF, Reisfield RA. Unique glycoprotein-proteoglycan complex defined by monoclonal antibody on human melanoma cells. Proc Natl Acad Sci USA 1982; 79: 1245-9.

8 Wilson BS, Ruberto G, Ferrone S. Immunochemical characterization of a human high molecular weight melanoma-associated antigen identified with monoclonal antibodies. Cancer Immunol Immunother 1983; 14: 196-201.

$9 \mathrm{Kau} \mathrm{Ng} \mathrm{AH}$, Giacomini P, Kantor R, Ferrone S. Molecular heterogeneity and shedding of a high-molecular-mass melanomaassociated antigen identified with monoclonal antibodies. Clin Chem 1982; 28: 2347-50.

10 Taylor-Papadimitriou J, Peterson J, Arklie JA, Burchell J, Ceriani RL, Bodmer WF. Monoclonal antibodies to epitheliumspecific components of human milk fat globule membrane: production and reaction with cells in culture. Int J Cancer 1981; 28: $17-21$.

11 Albert DM, Ruzzo MA, McLauglin MA, Robinson NL, Craft LJ, Epstein J. Establishment of cell lines of uveal melanoma. Invest Ophthalmol Vis Sci 1984; 25: 1284-99.

12 Alexander RA, Hiscott PS, Hart RL, Grierson I. Effects of melanin bleaching on immunoperoxidase with reference to ocular tissue and lesions. Med Lab Sci 1985; 42: 1-7.

13 Dippold WG, Lloyd KO, Li LTC, Ikeda H, Oettgen HF, Old LJ. Cell surface antigens of human malignant melanoma: definition of six antigenic systems with mouse monoclonal antibodies. Proc Natl Acad Sci USA 1980; 77: 6114-8.

14 Muralt B de, Tribolet N de, Discrens A-C, Stavrou D, Mach JP, Carrel S. Phenotyping of 60 cultured human gliomas and 34 other neuroectodermal tumours by means of monoclonal antibodies against glioma, melanoma and HLA-DR antigens. Eur $J$ Cancer Clin Oncol 1985; 21: 207-16.

15 Seeger RC, Rosenblatt HM, Imai K, Ferrone S. Common antigenic determinants on human melanoma, glioma, neuroblastoma and sarcoma cells defined with monoclonal antibodies. Cancer Res 1981; 41: 2714-7.

16 Buraggi GL, Turrin A, Cascinelli N, et al. Immuno-scintigraphy with antimelanoma monoclonal antibodies. In: Donato $\mathrm{L}$, Britton KE, eds. Immunoscintigraphy. London: Gordon and Breach, 1985: 215-54.

Accepted for publication 4 December 1986. 